\title{
SIMULTANEOUS DETERMINATION OF B-GROUP VITAMINS IN ENRICHED COOKIES
}

\author{
Tânia da Silveira Agostini-Costa \\ EMBRAPA, CP 3761, Fortaleza-CE, Brazil \\ Rodrigo Scherer, Cláudia Hoffmann Kowalski, Marcelo Alexandre Prado and Helena Teixeira Godoy* \\ Departamento de Ciência de Alimentos, Faculdade de Engenharia de Alimentos, Universidade Estadual de Campinas, CP 6121, \\ 13083 - 970 Campinas-SP, Brazil
}

Recebido em 1/3/07; aceito em 6/9/07; publicado na web em 10/3/08

\begin{abstract}
The objective of this research was to determine the levels of enrichment of vitamins $\mathrm{B}_{1}, \mathrm{~B}_{2}, \mathrm{~B}_{6}$ and $\mathrm{B}_{3}$ in different types and brands of enriched cookies. The chromatographic separation was performed in a C18 column with gradient elution and UV detection at 254 and $287 \mathrm{~nm}$. The results show that only 5 of the 24 brands evaluated are in accordance with the Brazilian legislation with respect to the vitamin content declared on the labels. However, consumption of approximately 100-150 g of most of the brands supplies the recommended dietary intake for children and adults of the vitamins evaluated.
\end{abstract}

Keywords: thiamin; riboflavin; fortified foods.

\section{INTRODUCTION}

Vitamins are organic compounds, found in small amounts in foods, designated as nutrients because they cannot be synthesized by the body and are required to support health and well being. Vitamins catalyze numerous biochemical reactions. They are not direct sources of energy, however facilitate energy metabolism. ${ }^{1}$

In developed countries, food fortification has proven an effective and low-cost way to increase the micronutrient supply and reduce the consequences of micronutrient deficiencies. Faber ${ }^{2}$ evaluated the nutrient composition of complementary foods consumed by 612 month-old South African infants. The author concludes that the infants who consumed fortified infant products, such as cereals ready-to-eat, canned baby foods and formula milk powder, had significantly higher intakes of calcium, iron, zinc, vitamin A, thiamine, riboflavin, niacin, vitamin $\mathrm{B}_{6}$, vitamin $\mathrm{B}_{12}$ and vitamin $\mathrm{C}$ than infants who did not consume any fortified products. The riboflavin and folate status have a significantly increase by use of multinutrient fortified beverages in children (age 6-11 years). ${ }^{3}$ Tucker et $a l .{ }^{4}$ assessed the effect of breakfast cereal fortified with folic acid, vitamin $\mathrm{B}_{6}$, and vitamin $\mathrm{B}_{12}$ on vitamin and homocysteine status. Group of volunteers, consumption of 1 cup fortified breakfast cereal daily significantly increased B vitamin and decreased homocysteine concentrations, in agreement with Robertson et al.. ${ }^{5}$

Although a great variety of enriched foods with vitamin B complex are available on the Brazilian market, the tremendous diversity of types and brands of vitamin enriched cookies makes them one the main vehicles of these vitamins, especially when one considers the level of consumption. ${ }^{6}$ So, the levels of fortification must be agreement with the specific legislation, besides the amount vitamin added by producers must be agreement with the declared values on the package. However, the Brazilian consumption data of enriched foods are unknown.

Some industrial processes used in the production of enriched foods may affect the levels of nutrients in the final product, especially vitamins, due the low stability. No measurable loss of thiamin $\left(\mathrm{B}_{1}\right)$ has been observed during the production and baking of loaves, and

*e-mail: helena@fea.unicamp.br losses during storage of these products are minimal. However, it is extensively destroyed during the baking of cookies, due the great surface area and to the high $\mathrm{pH}$ value, which is a result of substitution of the yeast by soda. ${ }^{7}$ Which a view to stability, thiamin mononitrate has been the form of the vitamin most widely used to enrich cereal derivatives. Thiamin is especially heat-labile, while folic acid, pyridoxine (B6) and particularly riboflavin $\left(\mathrm{B}_{2}\right)$ are highly light sensitive, which can be a problem in the case of transparent packages, the increasing with increased temperature and $\mathrm{pH} .{ }^{8}$ However, the conventional heating of milk produces destruction of vitamin $\mathrm{B}_{1}$ in milk. ${ }^{9}$ Bell and White ${ }^{10}$ reported that the glass transition effects (mobility considerations, collapse) have a larger effect on thiamin stability than water activity, which should be recognized during the development of fortified food products. Niacin $\left(\mathrm{B}_{3}\right)$ is one the most stable vitamins, and, as a function of alkaline treatment, such as that used in tortilhas and cookies there is an increase in niacin assimilation, probably due the hydrolysis of bound niacin during baking. ${ }^{11}$ In pork roasts, the vitamin $\mathrm{B}_{1}$ and vitamin $\mathrm{B}_{6}$ declined significantly, by $14 \%$ and $21 \%$ respectively, during $3 \mathrm{~h}$ of warmholding. ${ }^{12}$

The determination of B-group vitamins in food products has been done by microbiological methods. ${ }^{13,14}$ by gas chromatography, ${ }^{15}$ by capillary isotachophoresis ${ }^{16}$ and HPLC..$^{17-24}$ The simple HPLC method developed by Agostini and Godoy ${ }^{25}$ permits simultaneous determination of four vitamins $\left(B_{1}, B_{2}, B_{6}\right.$ and two different forms of $B_{3}$ ) in enriched foods with speed, simplicity and versatility. So, the aim of this study was the simultaneous determination of vitamins $\mathrm{B}_{1}, \mathrm{~B}_{2}, \mathrm{~B}_{6}$ and $\mathrm{B}_{3}$ by HPLC in enriched cookies.

\section{EXPERIMENTAL}

Twenty four types/brands of enriched biscuits were acquired, including 5 brands of maize flour cookies, 5 brands of milk cookies, 4 brands of corn flour cookies, 2 brands of coconut cookies and 8 brands of cream cookies with strawberry and chocolate fillings. The samples were bought in the city of Campinas (SP) with the exception of brand RC, which came from Fortaleza (CE). For each type of cookies 3 different lots were analyzed, and for each lot, the whole content of 3 packages was homogenized in a food multiprocessor. 
The fillings of the cream cookies were removed before homogenizing, however, the results were corrected back for the whole sample, considering the total weight. All determinations were carried out in duplicate. Immediately after to obtain the samples, it were kept in the refrigerator until the analysis. This way, the samples were protected against light and high temperature. After the analyses, the samples were stored in the refrigeration again, to allow the repetition if it was necessary.

The standards of thiamin mononitrate (vitamin $\mathrm{B}_{1}$ ), riboflavin (vitamin $\mathrm{B}_{2}$ ), pyridoxine hydrochloride (vitamin $\mathrm{B}_{6}$ ), nicotinic acid (vitamin PP) and nicotinamide (vitamin PP) were provided by $\mathrm{F}$. Hoffman-La Roche. The sodium salt of 1-hexanesulfonic acid, approx. 98\%, was provided by Sigma. Methanol (Omnisolv) and acetonitrile, both of chromatographic grade, and triethylamine for synthesis, were obtained by Merck. All the other chemical reagents were of analytical grade and were obtained in the local market. The water used in the preparation of mobile phases was purified in the Milli-Q system (Millipore). The mobile phases were filtered through Fluoropore filters (Millipore HAWP 0013) with $0.45 \mu \mathrm{m}$ diameter pores, and degassed in an ultrasonic bath.

A Varian liquid chromatograph was used, equipped with a model 9010 ternary pump, a manual Rheodyne type injector with a $20 \mu \mathrm{L}$ loop and a model 9065 polychromatic diode array detector. The system was coupled to a Varian integrator, model 4400. The analytical column used was a 150 x $4.6 \mathrm{~mm}, 5 \mu \mathrm{m}$ Spherisorb ODS2 column (Sigma-Aldrich) with a $5 \mu \mathrm{m}$ ODS-1 guard column (Varian), packed in the laboratory.

Some precautions were done to avoid the enzyme degradation, such as protection against the light and high temperature, and speed in the conclusion of the analyses. The vitamin determinations were carried out according to Agostini and Godoy. ${ }^{25}$ Between 4.0 and $5.0 \mathrm{~g}$ of previously homogenized sample were used for the vitamin extractions, carried out with $45 \mathrm{~mL}$ of $0.05 \mathrm{~mol} \mathrm{~L}^{-1}$ sulfuric acid for $60 \mathrm{~min}$ in an ultrasonic bath. The clean up of the extract was effected by the addition of sufficient methanol to complete to $100 \mathrm{~mL}$, followed by refrigeration for $60 \mathrm{~min}$ at $-18{ }^{\circ} \mathrm{C}$. The extract was then filtered first through common filter paper and then through Fluoropore filters with $0.50 \mu \mathrm{m}$ pores (Millipore FHLP 01300), before injection into the equipment.

The vitamin separation was performed at room temperature at a flow rate of $0.7 \mathrm{~mL} \mathrm{~min}^{-1}$ and with a gradient from $2 \%$ acetonitrile and $98 \%$ aqueous phase (hexanesulfonic acid - HSA $5 \mathrm{mmol} \mathrm{L}^{-1}$; $0.15 \%$ triethylamine - TEA; adjusted to $\mathrm{pH} 2.8$ with dilute $\mathrm{H}_{2} \mathrm{SO}_{4}$ ) at the start of the run to $3 \%$ acetonitrile and $97 \%$ aqueous phase after 3 min, followed by a linear gradient up to $2 \%$ acetonitrile, $41 \%$ aqueous phase and $57 \%$ methanol $20 \mathrm{~min}$ later. After returning to the initial conditions, the column was re-equilibrated for $20 \mathrm{~min}$. The vitamins were detected by ultra violet absorption at $254 \mathrm{~nm}$ for the first $9 \mathrm{~min}$, at $287 \mathrm{~nm}$ between 9 and $15 \mathrm{~min}$ and then at $254 \mathrm{~nm}$ again up to the end of the run at $20 \mathrm{~min}$. Identification was by comparison of retention times using standards analyzed under identical conditions, cochromatography and absorption spectra provided by the diode arrangement detector to the vitamins with specific spectrum. Quantification has been done by external standard curves with 6 concentration levels and were realized in triplicate. The concentration of standard solutions to vitamin were for: $\mathrm{B}_{1}-5.11,20.44,40.88$, 61.32, 81.76 and $102.2 \mu \mathrm{g} 100 \mathrm{~mL}^{-1} ; \mathrm{B}_{2}-3.99,15.96,31.92,47.88$, 63.84 and $79.8 \mu \mathrm{g} 100 \mathrm{~mL}^{-1} ; \mathrm{B}_{6}-6.09,24.36,48.72,73.08,97.44$ and $121.8 \mu \mathrm{g} 100 \mathrm{~mL}^{-1}$; nicotinamide - 50.75, 203, 406, 609, 812 and $1015 \mu \mathrm{g} 100 \mathrm{~mL}^{-1}$; and nicotinic acid - 11.67, 46.68, 93.36, 140.04, 186.72 and $233.4 \mu \mathrm{g} 100 \mathrm{~mL}^{-1}$. Tests for the recovery of standards were carried out in triplicate by spiking at five different concentration levels, using non-enriched maize flour cookies.

\section{Statistical analysis}

Experimental results were analyzed by Statistica 6.0 data analysis software by Statsoft, Inc, USA. $P$-values $<0.05$ were regarded as significant (ANOVA).

\section{RESULTS AND DISCUSSION}

The method shown a good linearity for the evaluated concentrations, the regression coefficient $\left(\mathrm{r}^{2}\right)$ was 0.9973, 0.9982, 0.9986, 0.9992 and 0.9989 for vitamins $\mathrm{B}_{1}, \mathrm{~B}_{2}, \mathrm{~B}_{6}$, nicotinamide and nicotinic acid, respectively. The chromatographic profiles of the vitaminic extracts of some of the cookie samples can be seen in Figure 1. The HPLC methodology used can rapidly separate and quantify all vitamins with high sensitivity and reliability. To certify for the absence of co-eluents, the degree of purity of each peak was observed from the purity parameter determinated by the equipment (ratio between the absorbencies of each vitamin obtained at two different wavelengths). The parameter for purity obtained for the vitamins present in cookies analyzed, were compared with those of the standards, and the agreement between the values indicated that non-existence of co-eluents, confirming the good resolution of the system for separating the vitamins. The recovery rates for vitamins determined by HPLC in non-enriched maize flour cookies, varied between 96 and $114 \%$ for concentrations between 5 and $100 \mu \mathrm{g} 100$ $\mathrm{mL}^{-1}$ of vitamins $\mathrm{B}_{1}, \mathrm{~B}_{2}$ and $\mathrm{B}_{6}$, and between 100 and $750 \mu \mathrm{g} 100$ $\mathrm{mL}^{-1}$ of nicotinamide (ND). The rates varied between 75 and $88 \%$ for concentrations between 15 and $175 \mu \mathrm{g} 100 \mathrm{~mL}^{-1}$ of nicotinic acid (NA). These results were similar to the Mann et al., ${ }^{26}$ where the recovery data to vitamin $\mathrm{B}_{6}$ varied between 81.4 and $98.0 \%$ (mean $=89.8 \%)$ in a collaborative study.
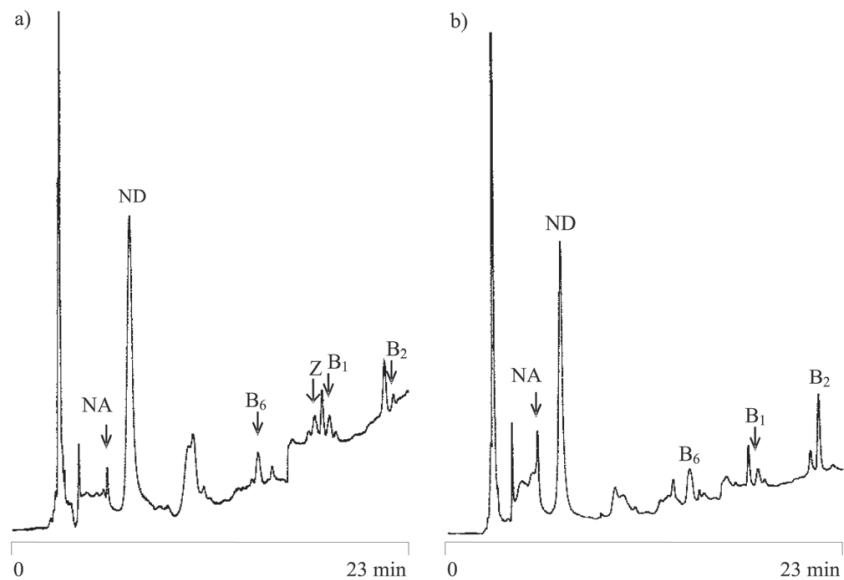

Figure 1. Chromatographic profile of the vitamins nicotinic acid (NA), nicotinamide $(N D) B_{6}, B_{1}$ and $B_{2}$ of (a) strawberry cookies $N S$; (b) coconut cookies BD. Column: ODS-2, $5 \mu \mathrm{m}, 150 \times 4.6 \mathrm{~mm}$. Solvent: $2 \%$ acetonitrile and $98 \%$ aqueous phase $\left(5 \mathrm{mmol} \mathrm{L}^{-1}\right.$ SHA; $0.15 \%$ TEA; pH 2.8 with $10 \%$ $\mathrm{H}_{2} \mathrm{SO}_{4}$ ) at the start of the run, 3\% acetonitrile and $97 \%$ aqueous phase after 3 min.; $2 \%$ acetonitrile, $41 \%$ aqueous phase and 57\% methanol after 23 min. Flow rate: $0.7 \mathrm{~mL} \mathrm{~min}^{-1}$. Detection at $254 \mathrm{~nm}$ for the first $9 \mathrm{~min}$., at 287 $\mathrm{nm}$ between 9 and $15 \mathrm{~min}$ and then at $254 \mathrm{~nm}$ again up the end of the run

Tables 1 to 6 show the vitamin levels determinated in the different types of cookies. The most of the standard deviations (SD) was below of 1.0 and the higher SD was 2.3 to ND analysis in a NB sample. In chocolate cream cookies, an interferent, probably present in the cacao, hindered the determination of vitamin $\mathrm{B}_{6}$. Arella et al. ${ }^{19}$ found similar results in a collaborative study to re-evaluate the chromatographic 
method proposed as the official French method. With all the foodstuffs studied, the recovery rate of the method was always superior to $89 \%$, except with the chocolate powder, for which it reduced to approximately $50 \%$ for vitamin $\mathrm{B}_{1}$ and $75 \%$ for vitamin $\mathrm{B}_{2}$.

All the different types of cookies of the NS brands presented $30 \%$ of the vitamin $\mathrm{B}_{2}$ declared on the label. These low levels could be a result of degradation during the processing of the cookies. Penteado ${ }^{27}$ report that the vitamin $\mathrm{B}_{2}$ is very resistant to the heat and has been stable during the food cooking, however, the vitamin $\mathrm{B}_{2}$ content may be reduced by light exposition. A chromatographic peak (Z), with a retention time 4-5 min shorter than that of vitamin $\mathrm{B}_{2}$ (Figure 1), detected only in biscuits of this brand, presented the same absorption spectrum profile as riboflavin, suggesting that it a was a degradation product of vitamin $\mathrm{B}_{2}$. By coincidence, the sum of the two peaks would provide the vitamin levels declared on the peak. The CR maize flour cookies presented $70 \%$ of the declared value for vitamin $\mathrm{B}_{2}$. The coconut cookies of the brand BD presented vitamin levels approximately twice the amounts declared on the packages, while as the TD maize flour and $\mathrm{RC}$ milk cookies presented the vitamins $\mathrm{B}_{1}$ and $\mathrm{B}_{6}$ approximately twice of declared values.

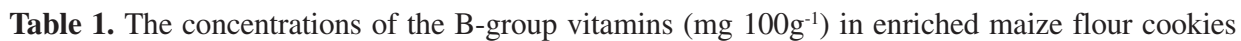

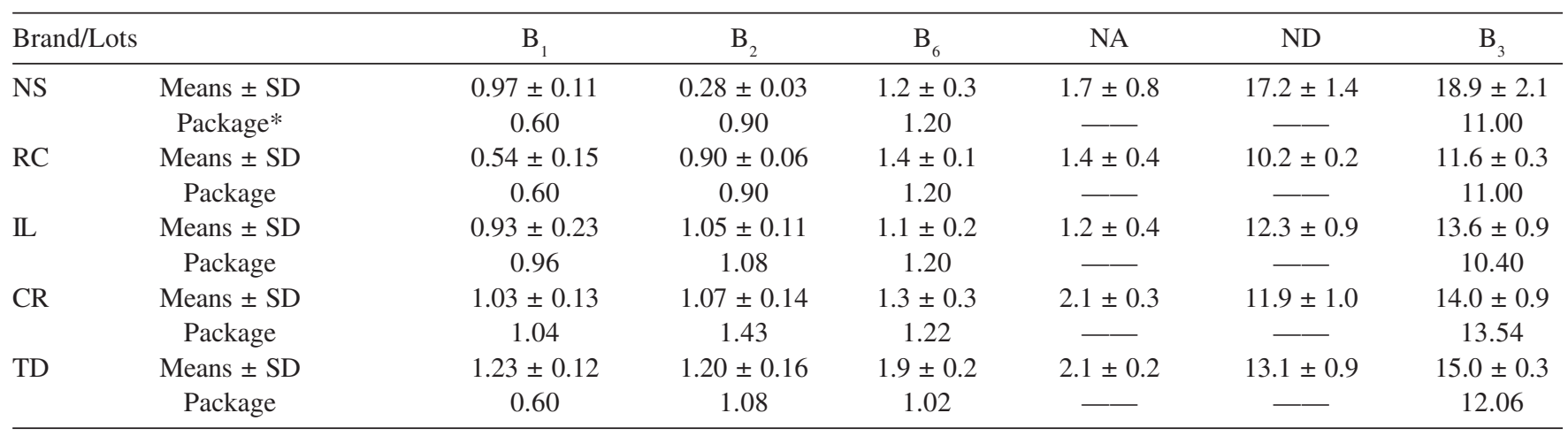

Means of the three lots. $\mathrm{B}_{1}$ : thiamin; $\mathrm{B}_{2}$ : riboflavin; $\mathrm{B}_{6}$ : pyridoxine; NA: nicotinic acid; ND: nicotinamide; $\mathrm{B}_{3}=\mathrm{NA}+\mathrm{ND} ; \mathrm{SD}$ : standard deviation; — : not declared. The coefficients of variation calculated for $\mathrm{B}_{1}, \mathrm{~B}_{2}$ and ND are less than $5 \%$ and for $\mathrm{NA}_{\text {and }} \mathrm{B}_{6}$ are less than $13 \%$. * Declared values.

Table 2. The concentrations of the B-group vitamins $\left(\mathrm{mg} 100 \mathrm{~g}^{-1}\right)$ in enriched corn flour cookies

\begin{tabular}{|c|c|c|c|c|c|c|c|}
\hline \multicolumn{2}{|c|}{ Brand/Lots } & \multirow{2}{*}{$\begin{array}{c}\mathrm{B}_{1} \\
0.86 \pm 0.07 \\
0.60\end{array}$} & \multirow{2}{*}{$\begin{array}{c}\mathrm{B}_{2} \\
0.23 \pm 0.05 \\
0.90\end{array}$} & \multirow{2}{*}{$\begin{array}{c}\mathrm{B}_{6} \\
1.3 \pm 0.2 \\
1.20\end{array}$} & \multirow{2}{*}{$\frac{\mathrm{NA}}{1.8 \pm 0.1}$} & \multirow{2}{*}{$\frac{\text { ND }}{15.1 \pm 0.4}$} & \multirow{2}{*}{$\begin{array}{c}\mathrm{B}_{3} \\
16.9 \pm 0.3 \\
11.00\end{array}$} \\
\hline NS & $\begin{array}{c}\text { Means } \pm \text { SD } \\
\text { Package* }\end{array}$ & & & & & & \\
\hline TR & $\begin{array}{c}\text { Means } \pm \text { SD } \\
\text { Package }\end{array}$ & $\begin{array}{c}0.77 \pm 0.29 \\
0.60\end{array}$ & $\begin{array}{c}1.06 \pm 0.15 \\
0.90\end{array}$ & $\begin{array}{c}1.6 \pm 0.1 \\
1.20\end{array}$ & $\begin{array}{c}1.5 \pm 0.6 \\
-\end{array}$ & $\begin{array}{c}13.0 \pm 0.7 \\
-\end{array}$ & $\begin{array}{c}14.6 \pm 1.3 \\
11.00\end{array}$ \\
\hline IL & $\begin{array}{c}\text { Means } \pm \text { SD } \\
\text { Package }\end{array}$ & $\begin{array}{c}1.30 \pm 0.18 \\
0.96\end{array}$ & $\begin{array}{c}1.14 \pm 0.21 \\
1.08\end{array}$ & $\begin{array}{c}1.0 \pm 0.2 \\
1.20\end{array}$ & $\begin{array}{c}1.3 \pm 0.3 \\
-\end{array}$ & $\begin{array}{c}12.0 \pm 2.0 \\
-\end{array}$ & $\begin{array}{c}13.3 \pm 1.8 \\
10.40\end{array}$ \\
\hline CR & $\begin{array}{c}\text { Means } \pm \text { SD } \\
\text { Package }\end{array}$ & $\begin{array}{c}1.03 \pm 0.14 \\
1.07\end{array}$ & $\begin{array}{c}1.22 \pm 0.13 \\
1.47\end{array}$ & $\begin{array}{c}1.4 \pm 0.5 \\
1.26\end{array}$ & $\begin{array}{c}1.8 \pm 0.6 \\
-\end{array}$ & $\begin{array}{c}11.3 \pm 1.0 \\
-\end{array}$ & $\begin{array}{c}13.1 \pm 0.4 \\
13.89\end{array}$ \\
\hline
\end{tabular}

Means of the three lots. NA: nicotinic acid; ND: nicotinamide; PP vitamin = NA+ND; SD: standard deviation; ——: not declared. The coefficients of variation calculated for $\mathrm{B}_{1}, \mathrm{~B}_{2}$ and nicotinamide are less than $5 \%$ and for nicotinic acid and $\mathrm{B}_{6}$ are less than $13 \%$. $*$ Declared values

Table 3. The concentrations of the B-group vitamins $\left(\mathrm{mg} 100 \mathrm{~g}^{-1}\right)$ in enriched milk cookies

\begin{tabular}{|c|c|c|c|c|c|c|c|}
\hline Brand/Lots & & $\mathrm{B}_{1}$ & $\mathrm{~B}_{2}$ & $\mathrm{~B}_{6}$ & NA & ND & $\mathrm{B}_{3}$ \\
\hline $\mathrm{BD}$ & $\begin{array}{c}\text { Means } \pm \text { SD } \\
\text { Package* }\end{array}$ & $\begin{array}{c}0.98 \pm 0.11 \\
0.60\end{array}$ & $\begin{array}{c}1.6 \pm 0.2 \\
0.90\end{array}$ & $\begin{array}{c}1.7 \pm 0.3 \\
1.20\end{array}$ & $\begin{array}{c}1.2 \pm 0.7 \\
-\end{array}$ & $\begin{array}{c}14.8 \pm 1.1 \\
-\end{array}$ & $\begin{array}{c}15.8 \pm 0.7 \\
10.20\end{array}$ \\
\hline TR & $\begin{array}{c}\text { Means } \pm \text { SD } \\
\text { Package }\end{array}$ & $\begin{array}{c}0.68 \pm 0.08 \\
0.60\end{array}$ & $\begin{array}{c}0.97 \pm 0.13 \\
0.90\end{array}$ & $\begin{array}{c}1.7 \pm 0.2 \\
1.20\end{array}$ & $\begin{array}{c}1.6 \pm 0.8 \\
-\end{array}$ & $\begin{array}{c}11.7 \pm 0.8 \\
\end{array}$ & $\begin{array}{c}13.3 \pm 1.6 \\
11,00\end{array}$ \\
\hline $\mathrm{RC}$ & $\begin{array}{c}\text { Means } \pm \text { SD } \\
\text { Package }\end{array}$ & $\begin{array}{c}1.22 \pm 0.09 \\
0.60\end{array}$ & $\begin{array}{c}1.10 \pm 0.05 \\
0.90\end{array}$ & $\begin{array}{c}1.7 \pm 0.2 \\
1.20\end{array}$ & $\begin{array}{c}0.9 \pm 0.3 \\
-\end{array}$ & $\begin{array}{c}13.3 \pm 0.7 \\
-\end{array}$ & $\begin{array}{c}14.2 \pm 0.5 \\
11.00\end{array}$ \\
\hline CR & $\begin{array}{c}\text { Means } \pm \text { SD } \\
\text { Package }\end{array}$ & $\begin{array}{c}0.70 \pm 0.16 \\
0.60\end{array}$ & $\begin{array}{c}1.40 \pm 0.17 \\
0.90\end{array}$ & $\begin{array}{c}2.2 \pm 0.1 \\
1.20\end{array}$ & $\begin{array}{c}0.8 \pm 0.2 \\
-\end{array}$ & $\begin{array}{c}14.8 \pm 0.8 \\
-\end{array}$ & $\begin{array}{c}15.6 \pm 1.0 \\
11.00\end{array}$ \\
\hline $\mathrm{BL}$ & $\begin{array}{l}\text { Means } \pm \text { SD } \\
\text { Package }\end{array}$ & $\begin{array}{c}1.49 \pm 0.1 \\
0.96\end{array}$ & $\begin{array}{c}1.23 \pm 0.09 \\
1.08\end{array}$ & $\begin{array}{c}1.5 \pm 0.2 \\
1.20\end{array}$ & $\begin{array}{c}1.2 \pm 0.4 \\
-\end{array}$ & $\begin{array}{c}11.7 \pm 0.8 \\
-\end{array}$ & $\begin{array}{c}12.9 \pm 0.8 \\
10.40\end{array}$ \\
\hline
\end{tabular}

Means of the three lots. NA: nicotinic acid; ND: nicotinamide; PP vitamin = NA+ND; SD: standard deviation; ——: not declared. The coefficients of variation calculated for $\mathrm{B}_{1}, \mathrm{~B}_{2}$ and nicotinamide are less than $5 \%$ and for nicotinic acid and $\mathrm{B}_{6}$ are less than $13 \%$. $*$ Declared values. 
Table 4. The concentrations of the B-group vitamins $\left(\mathrm{mg} 100 \mathrm{~g}^{-1}\right)$ in enriched coconut cookies

\begin{tabular}{|c|c|c|c|c|c|c|c|}
\hline Brand/Lots & & $\mathrm{B}_{1}$ & $\mathrm{~B}_{2}$ & $\mathrm{~B}_{6}$ & NA & ND & $\mathrm{B}_{3}$ \\
\hline \multirow[t]{2}{*}{ NS } & Means \pm SD & $0.87 \pm 0.3$ & $0.30 \pm 0.1$ & $1.0 \pm 0.1$ & $1.0 \pm 0.8$ & $14.3 \pm 0.9$ & $15.3 \pm 1.3$ \\
\hline & Package* & 0.60 & 0.90 & 1.20 & - & - & 11.00 \\
\hline \multirow[t]{2}{*}{ BD } & Means \pm SD & $1.13 \pm 0.4$ & $1.82 \pm 0.2$ & $2.2 \pm 0.2$ & $1.7 \pm 0.7$ & $18.0 \pm 1.1$ & $19.66 \pm 1.4$ \\
\hline & Package & 0.60 & 0.90 & 1.2 & - & - & 10.2 \\
\hline
\end{tabular}

Means of the three lots. NA: nicotinic acid; ND: nicotinamide; PP vitamin = NA+ND; SD: standard deviation; — coefficients of variation calculated for $\mathrm{B}_{1}, \mathrm{~B}_{2}$ and nicotinamide are less than $5 \%$ and for nicotinic acid and $\mathrm{B}_{6}$ are less than $13 \%$. $*$ Declared values.

Table 5. The concentrations of the B-group vitamins $\left(\mathrm{mg} 100 \mathrm{~g}^{-1}\right)$ in enriched chocolate cream cookies

\begin{tabular}{|c|c|c|c|c|c|c|c|}
\hline \multicolumn{2}{|c|}{ Brand/Lots } & $\mathrm{B}_{1}$ & $\mathrm{~B}_{2}$ & $\mathrm{~B}_{6}$ & NA & ND & $\mathrm{B}_{3}$ \\
\hline \multirow[t]{2}{*}{$\mathrm{CR}$} & Means $\pm \mathrm{SD}$ & $0.85 \pm 0.25$ & $0.88 \pm 0.08$ & - & $0.7 \pm 0.2$ & $10.0 \pm 0.2$ & $10.7 \pm 0.3$ \\
\hline & Package* & 0.60 & 0.90 & 1.20 & - & 11.00 & - \\
\hline \multirow[t]{2}{*}{ NB } & Means $\pm \mathrm{SD}$ & $0.77 \pm 0.15$ & $1.12 \pm 0.14$ & $1.13 \pm 0.40$ & $1.59 \pm 0.16$ & $18.3 \pm 2.3$ & $21.2 \pm 0.5$ \\
\hline & Package & 0.8 & 0.9 & 1.3 & - & - & 12.0 \\
\hline \multirow[t]{2}{*}{$\mathrm{RC}$} & Means \pm SD & $0.82 \pm 0.16$ & $1.00 \pm 0.07$ & $1.5 \pm 0.2$ & $0.6 \pm 0.2$ & $11.1 \pm 0.1$ & $11.7 \pm 0.1$ \\
\hline & Package & 0.60 & 0.90 & 1.20 & - & - & 11.0 \\
\hline \multirow[t]{2}{*}{$\mathrm{CR}$} & Means $\pm \mathrm{SD}$ & $0.91 \pm 0.17$ & $1.17 \pm 0.07$ & $1.6 \pm 0.2$ & $0.9 \pm 0.4$ & $13.3 \pm 0.4$ & $14.2 \pm 0.8$ \\
\hline & Package & 0.60 & 0.90 & 1.20 & - & - & 11.0 \\
\hline
\end{tabular}

Means of the three lots. NA: nicotinic acid; ND: nicotinamide; PP vitamin = NA+ND; SD: standard deviation; — coefficients of variation calculated for $\mathrm{B}_{1}, \mathrm{~B}_{2}$ and nicotinamide are less than $5 \%$ and for nicotinic acid and $\mathrm{B}_{6}$ are less than $13 \%$. * Declared values.

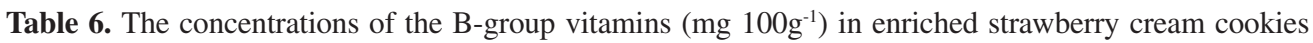

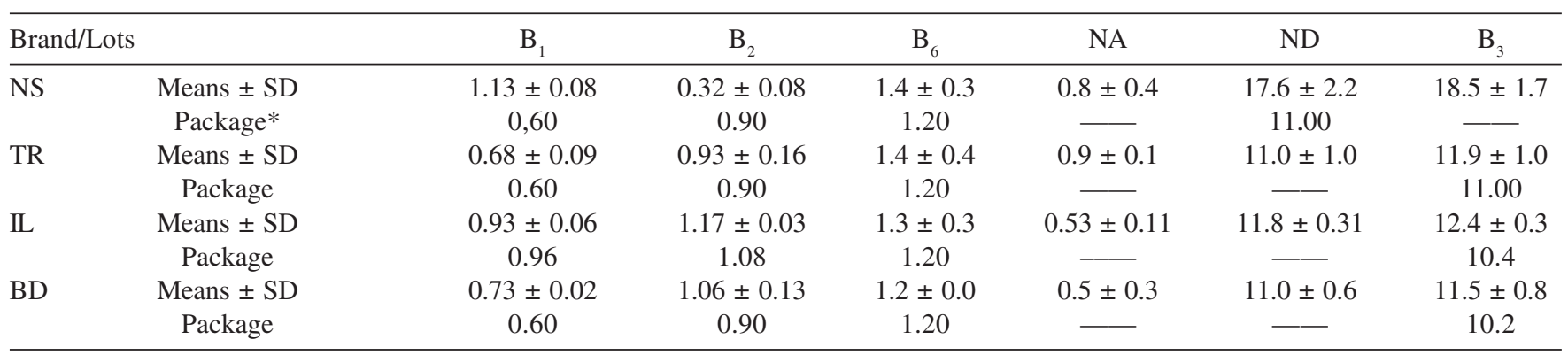

Means of the three lots. NA: nicotinic acid; ND: nicotinamide; PP vitamin = NA+ND; SD: standard deviation; ——: not declared. The coefficients of variation calculated for $\mathrm{B}_{1}, \mathrm{~B}_{2}$ and nicotinamide are less than $5 \%$ and for nicotinic acid and $\mathrm{B}_{6}$ are less than $13 \%$. $*$ Declared values.

The stability and concentration of $\mathrm{B}$ group vitamins $\left(\mathrm{B}_{1}, \mathrm{~B}_{2}\right.$, $\mathrm{B}_{3}, \mathrm{~B}_{5}$ and $\mathrm{B}_{6}$ ) was evaluated in isotonic beverages and power beverages, the amount of some vitamins was found 15 times above of the declared on the labels, even after the shelf life had been exceeded. ${ }^{28}$ The vitamin A palmitate losses in corn flakes fortified after $6-8$ week storage was more than $90 \%$ in all samples, and the presence of other vitamins $\mathrm{B}_{1}, \mathrm{~B}_{6}, \mathrm{~B}_{12}, \mathrm{C}$, and $\mathrm{D}$ reduced the loss of vitamin $\mathrm{A}$, but the loss was still significant. ${ }^{29}$ Albalá-Hurtado et al. ${ }^{30}$ found only $50 \%$ of declared value to $\mathrm{B}_{2}$ vitamin, and nicotinamide and $\mathrm{B}_{6}$ vitamins were found above of the declared levels in infant milks. In other paper, the stability of vitamins $\mathrm{E}, \mathrm{A}$, $\mathrm{B}_{1}, \mathrm{~B}_{2}, \mathrm{~B}_{6}$ and nicotinamide were evaluated in two forms of infant milks. The authors related that only vitamin A shows significant losses, however the final concentration was higher than the minimal set by Spanish legislation. ${ }^{31}$

The Brazilian legislation ${ }^{32}$ only admits a variation of the $20 \%$ more of the declared values on the package in relation of the nutrients and caloric value. So, only 5 (IL and RC maize flour; BD, IL and TR strawberry cream cookies) of the 24 brands evaluated are in accordance with the Brazilian legislation, the other brands have one or more vitamin in disagreement with legislation values.

The recommended dietary intake (RDI) is the intake amount that is sufficient to meet the nutrient requirement for nearly all healthy individuals in a group. The RDI is expressed as a single value set separately for each sex and specific age group. The magnitude of the discrepancy from the RDI and the duration of the nutritional deficit determine whether adverse effects on health and well being occur. According to the Brazilian legislation, ${ }^{33}$ the RDI to children's (7-10 ages) and adults, for the $\mathrm{B}_{1}, \mathrm{~B}_{2}, \mathrm{~B}_{6}$ and $\mathrm{B}_{3}$ vitamins are respectively, 1.0, 1.2, 1.4 and $13 \mathrm{mg}$, and 1.4, 1.6, 2.0 and 18 mg. So, approximately 100-150 g of the most brands supplies the RDI for children's and adults, except the vitamin $B_{2}$ in NS brand, which is necessary approximately $400 \mathrm{~g}$.

No relation was observed between the vitamin levels and the different types of cookies analyzed. The various types of cookies of brand NS, TR and IL showed similar vitamin levels within the same brand. Of the $\mathrm{BD}$ and $\mathrm{CR}$ cookies, the cream biscuits presented the lowest vitamin levels. Total means of each vitamin determinated in 
the different types of cookies manufactured by the same industry, of which three or more enriched types of cookies were analyzed. These levels were significantly different $(P<0.05)$ only for vitamin $\mathrm{B}_{2}$ in the brand NS, indicating that the different manufacturers presented similar levels of enrichment in their products.

\section{CONCLUSION}

The most of brands evaluated are in disagreement with the Brazilian legislation in relation of the vitamins declared values on the labels. The CR and NS brand cookies presented approximately 70 and $30 \%$ respectively of the levels of vitamin $B_{2}$ declared on their packages. The BD brand coconut cookies presented approximately double the declared amounts of vitamin. In chocolate cream cookies, the $B_{6}$ vitamin analysis was difficult by interference. Approximately 100-150 g of the most brands evaluated supply the Recommended Dietary Intakes (RDI) according to the Brazilian legislation. So, the enriched cookies evaluated are good source of B-group vitamins, and could be used in populations at risk for vitamin deficiencies, as know the high level of consumption these products, especially for children's. However, the quality control must be better in relation of the declared values on the labels.

\section{ACKNOWLEDGMENT}

The authors wish to thanks the Conselho Nacional de Pesquisa (CNPq) for financial support.

\section{REFERENCES}

1. Lukaski, H. C.; Nutrition 2004, 20, 632.

2. Faber, M.; Public Health Nutrition 2005, 8, 373.

3. Abrams, S. A.; Mush, A.; Hilmers, D. C.; Griffin, I. J.; Davila, P.; Allen, L.; Botswana J. Nutrition 2003, 133, 1834.

4. Tucker, K. L.; Olson, B.; Bakun, P.; Dallal, G. E.; Selhub, J.; Rosenberg, I. H.; Am. J. Clin. Nutr. 2004, 79, 805.

5. Robertson, J.; Iemolo, F.; Stabler, S. P.; Allen, R. H.; Spence, J. D.; Can. Med. Assoc. J. 2005, 172, 1569.

6. http://www.lafis.com.br/lafis/portugues/Demos/DemosMassas.pdf, acessada em Março 2006.
7. Ranhotra, G. S.; Gelroth, J. A.; Cereal Chem. 1986, 63, 401.

8. Tannenbaum, S. R.; Young, V. R.; Archer, M. C. In Química de los Alimentos; Fennema, O. R., ed.; Acribia: Zaragoza, 1993.

9. Sierra, I.; Vidal-Valverde, C.; Olano, A.; Eur. Food Res. Technol. 1999, 209, 352 .

10. Bell, L. N.; White, K. L.; J. Food Sci. 2000, 65, 498.

11. Bock, M. A. In Handbook of cereal science and technology; Lorenz, K. J.; Kulp, K., eds.; Marcel Decker Inc.: New York, 1991.

12. Lassen, A.; Kall, M.; Hansen, H.; Ovesen, L.; Eur. Food Res. Technol. 2002, 215, 194.

13. Tanner, J. T.; Smith, J.; Defibaugh, P.; Angyal, G.; Villalobos, M.; Bueno, M. P.; McGarrahan, E.; Wehr, H. M.; Muniz, J. F.; Hollis, B. W.; Koh, Y.; Reich, P.; Simpson, K. L.; J. AOAC Int. 1988, 71, 607.

14. Premaratne, R. J.; Cousin, M. A.; J. Dairy Sci. 1991, 74, 788.

15. Lin, H. J.; Chen, C. W.; Hwang, B. S.; Choong, Y. M.; J. Food Drug Anal. $2000,8,113$.

16. Sádecká, J.; Karasová, G.; Polonský, J.; Eur. Food Res. Technol. 2003, 216 , 440 .

17. Chase, G. W.; Landen, W. O.; Eiternmiller, R. R.; Soliman, A. G.; J. AOAC Int. 1992, 75, 561 .

18. Muñoz, A.; Ortiz, A.; Murcia, M. A.; Food Chem. 1994, 49, 203.

19. Arella, F.; Lahely, S.; Bourguignon, J. B; Hasselmann, C.; Food Chem. 1996, 56,81 .

20. Ollilainen, V.; Finglas, P. M.; van den Berg, H.; Froidmont-Gortz, I.; J. Agric. Food Chem. 2001, 49, 315.

21. Woollard, D. C.; Indyk, H. E.; J. AOAC Int. 2002, 85, 945.

22. Carver, J. D.; Am. J. Clin. Nutr. 2003, 77, 1550.

23. Vinas, P.; Balsalobre, N.; Lopez-Erroz, C.; Hernandez-Cordoba, M.; J. Agric. Food Chem. 2004, 52, 1789.

24. Zielinski, H.; Frias, J.; Piskula, M. K.; Kozlowska, H.; Vidal-Valverde, C.; Eur. Food Res. Technol. 2005, 21, 78.

25. Agostini, T. S.; Godoy, H. T.; J. High Resol. Chrom. 1997, 20, 245.

26. Mann, D. L.; Ware, G. M.; Bonnin, E.; Eitenmiller, R. R.; J. AOAC Int. 2005, 88,30 .

27. Penteado, M. V. C.; Vitaminas: Aspectos nutricionais, bioquímicas, clínicos e analíticos, Manole: Barueri, 2003, cap. 8.

28. Castro, F. J. de; Scherer, R.; Godoy, H. T.; Quim. Nova 2006, 29, 719.

29. Kim, Y. S.; Strand, E.; Dickmann, R.; Warthesen, J.; J. Food Sci. 2000, 65, 1216.

30. Albalá-Hurtado, S.; Veciana-Nogués, M. T.; Riera-Valls, E.; Mariné-Font, A.; Vidal-Carou, C.; J. Dairy Res. 2000, 67, 225.

31. Albalá-Hurtado, S.; Veciana-Nogués, M. T.; Vidal-Carou, C.; Mariné-Font, A; J. Food Sci. 2000, 65, 1052.

32. http://www.anvisa.gov.br/alimentos/legis/especifica/rotuali.htm, acessada em Julho 2005.

33. http://www.anvisa.gov.br/alimentos/legis/especifica/regutec.htm, acessada em Março 2005. 